\title{
THE HISTORY OF INITIAL TEACHER EDUCATION IN CANADA: QUÉBEC AND ONTARIO ${ }^{1}$
}

\author{
SMYTH, Elizabeth ${ }^{1}$; HAMEL, Thérèse ${ }^{2^{*}}$ \\ ${ }^{1}$ University of Toronto \\ ${ }^{2}$ Université Laval \\ therese.hamel@fse.ulaval.ca*
}

\begin{abstract}
This article traces the history of teacher education in Canada from the seventeenth century to the present by focusing on teacher education in the English-language dominant province of Ontario and the French-language dominant province of Québec. Because of the decentralized nature of education in Canada, it is at the provincial, not at the national level, where policies and practices for teacher education are developed and
\end{abstract}

delivered. Like the history of Canada itself, the history of teacher education is marked by conflicts of gender, religion, power, class, race, language and ethnicity as teacher education struggled to claim a space itself in the academy and exercise its authority within the ivory tower. The article considers how the historical struggles and successes can both inform and cause us to critically reflect our current practice.

KEYWORDS: Teacher training. Educational policy. Canada.

\section{RESUMO}

Este artigo traça a história da formação de professores no Canadá a partir do século XVII até o presente, centrando-se na formação de professores nos idiomas inglês, língua dominante na província de Ontário, e francês, língua dominante na província do Québec. Devido à natureza descentralizada da educação no Canadá, é na província, não em âmbito nacional, em que as políticas e práticas de formação de professores são desenvolvidas e entregues. Como a própria história do Canadá, a história da formação de professores é marcada por conflitos - de gênero, religião, poder, classe, raça, língua e etnia - que influenciam na maneira como a formação de professores lutou para reivindicar um espaço próprio na academia e exercer a sua autoridade dentro da torre de marfim. $O$ artigo considera como as lutas históricas e sucessos podem informar e suscitar reflexões críticas acerca das práticas atuais.

PALAVRAS-CHAVE: Formação de professores. Políticas educacionais. Canadá.

\section{RESUMEN}

Este artículo describe la historia de la formación docente en Canadá desde el siglo XVII hasta la actualidad, centrándose en la formación de los profesores de inglés, idioma dominante en la provincia de Ontario, y francés, idioma dominante en la provincia de Québec. Debido a la naturaleza descentralizada de la educación en Canadá, es a nivel provincial, no a nivel nacional, donde se desarrollan y entregan las políticas y prácticas de formación del profesorado. Al igual que la propia historia de Canadá, la historia de la formación del profesorado está marcada por los conflictos de género, religión, poder, clase, raza, lengua y etnicidad, que influyen en la manera como la formación de profesores se esforzó para reclamar un espacio propio en la academia y ejercer su autoridad dentro de la torre de marfil. El artículo considera cómo las luchas y éxitos históricos pueden informar y hacer con que se reflexione críticamente sobre las prácticas actuales.

PALABRAS CLAVE: Formación del profesorado. La política educativa. Canadá.

1 Artigo inicialmente publicado em Falkenberg (2015). 


\section{INTRODUCTION}

The history of teacher education in Canada is both simple and complex. It is the history of how the preparation of new teachers moved from a model based on training to one based on education; from an apprenticeship model to one of university-based education for a profession. As with the history of the development of teaching as a profession, the history of teacher education is at the same time a tale of inclusion and exclusion; of intransigence and compromise; of disputes concerning power and influence played out at a local, provincial, and national level. Like the history of Canada itself, it is marked by conflicts of gender, religion, power, class, race, language, and ethnicity as teacher education struggled to claim a space for itself in the academy.

Unlike many other countries, Canada does not have a national office of education. The 1867 British North America Act established education as a provincial responsibility. Thus each of the ten provinces and three territories regulate all aspects of primary school through to postsecondary education. This chapter explores how teachers were educated in two provinces of Canada, namely Ontario and Québec. These provinces were chosen for analysis because within their histories one finds both parallels and convergences. In each, the provincial government came to regulate where teacher education was delivered; to inform and frame decision making in admission (who presented themselves as teacher candidates) and in curriculum (what was taught in the program and by whom); and to determine the exit credential awarded. In both, the history of teacher education is not a triumphalist tale. In both, there is a history of how education in general and teacher education specifically, attempted to secure status as an academic discipline and to exercise its authority within the ivory tower. There are lessons to be learned here that can inform and cause critical reflection on current practice. While the focus of this chapter is teacher education in the period after the establishment of publicly funded schooling, it will begin by examining the state of teacher education before that.

\section{TEACHER EDUCATION PRIOR TO PUBLICLY FUNDED SCHOOLING}

The goal of teacher education is to effectively prepare those who deliver content to learners and to prepare the future generations of a society. As is the case with all settler societies 
in the imperial age, European immigrants brought with them a system of knowledge and values that was communicated to children through both private and state-sponsored schools. In New France, the state and the church were integrated to the extent that the first paid teachers were in fact members of the clergy and the religious life, whose prime objective was the conversion of the First Nations people, an objective that fit in clearly with the goals of economic and cultural domination. Marie Battiste (2002) has argued that although teachers, whom she classifies as knowledge workers, were a central part of First Nations society, they and the education they delivered were generally dismissed by the European immigrants.

The first formally educated teachers, the male Recollets Friars Minor (the Recollets) and the Society of Jesus (the Jesuits), and the female Order of St. Ursula (the Ursulines) were members of religious orders that had teaching as a key work. The Ursulines took a vow of teaching as well as the traditional vows of poverty, chastity, and obedience. Members of all three congregations lived under constitutions that defined their roles in community, outlined their governance structures, and regulated, often in minute detail, how they were to conduct their lives, including the pedagogical practices that they were to use. Religious orders were communities of teachers in which initial teacher education and ongoing teacher development were features of an educator's life. Within these orders, teaching was seen as a vocation and education a vehicle for evangelization. Yet, not all sisters, priests, and brothers who were prepared as teachers within such closed communities became model instructors.

As part of their novitiate, that is the first stage in the formation of a religious, men and women received both formal classroom instruction and opportunities for on-the-job training while they were being inducted into religious life. The calibre and effectiveness of that training varied greatly. In some cases, when there was demand from priests and bishops for religious to staff the rapidly expanding school systems, novice teachers were sometimes thrust into the classroom with no or minimal preparation. In other cases, teacher preparation program for the novices became the foundation of a post-secondary institution, as evidenced by the Sisters of Charity of Halifax, whose teacher education novitiate was the foundation of Mount St. Vincent University. To ensure consistency across schools and distances, (and in some instances to address the wide variance in teacher preparation), religious orders undertook the development of instructional materials that served as texts for teacher education programs, or, in other cases, 
were substitutes for teacher education. The work of Paul Aubin (2006) and Monique Lebrun (2007) clearly document these trends.

\section{INITIAL TEACHER EDUCATION IN QUÉBEC}

Throughout its history, both lay and religious teachers operated schools in New France and later in the province of Québec. In their analysis of local newspapers, Claude Galarneau (1990) and Andrée Dufour $(1993,1998)$, have documented how prior to publicly funded schooling, there were many instances of educational entrepreneurship by men and women in the city of Québec and Montréal. Michel Verette (2004) traces these schools as agencies of literacy throughout the colonies of British North America. Bruce Curtis (2012) has demonstrated that in the Lancasterian system, assigning some pupils the role of pupil teachers was used as an instructional strategy.

With the rise of publicly funded schools, teacher education became, to some degree, regulated and one might select from several paths to become a teacher. For members of religious orders, no preparation was required as instruction in the novitiate was considered sufficient. Yet, even without obligation to do so, religious congregations established scolasticatsécoles normales in the 1930s in order to more effectively prepare their members to become competent future teachers. The second path was through the normal schools. Québec's normal schools had a shaky and short-lived beginning in 1836. It was not until 1857 that three schools were established on firm footing. They were state funded and denominationally segregated. Montréal was the location of two: the Protestant McGill Normal School and the Catholic Jacques Cartier Normal School. Québec City was the location of a third, Laval's Normal School for the Catholics. It was not until 1939, with the foundation of Montréal's St. Joseph's Teachers' College, that anglophone Catholic teacher candidates had their own normal school.

The first state-controlled normal schools in Québec were state funded and, while they enrolled both men and women, the classes were segregated. Women pupils were taught by women religious. The Ursulines taught at the École normale Laval from 1857, and the Québecfounded Congregation of Notre Dame at École normale Jacques-Cartier from 1899 onward. Tensions between church and state characterized the history of teacher education, reaching a 
high point in 1881 with the Verreau-Laflèche struggle. Bishop Louis-Francois Laflèche of Trois Rivières and the principal of Laval Normal School, Hospice-Anthelme Jean Baptiste Verreau, had competing views of where teacher candidates should be educated. Verreau advocated a centralized model aimed at attracting the best candidates, whereas Bishop Laflèche sought to make teacher education accessible even in the most remote area of the Québec province by supporting a number of small normal schools. The vision of Laflèche prevailed and the province of Québec devolved teacher education from a central state-operated model, where normal schools were located in central cities, to an array of small, decentralized model schools, operated by religious orders and located in small towns throughout Québec. These schools were for women only and used an apprenticeship model, wherein future teachers taught alongside experienced teachers and in close proximity (both in terms of chronological age and working conditions) to those they instructed. In the larger institutions, there were laboratory schools (called écoles d'application) where the teacher candidates could practice in actual classrooms. A large number of religious orders took charge of this important segment of teacher preparation until the Quiet Revolution of the 1960s.

Admission qualifications to Québec's teacher preparation programs varied throughout the centuries. Between 1888 and 1940, the number of years of schooling required for admission ranged from a low of 7 years to a high of 13years, not significantly more than the oldest of their pupils. During this period, the focus of instruction was on preparing student teachers to deliver the curriculum, with little attention paid to gaining (or honing) pedagogical skills. Before 1939, the year when the Bureau central des examinateurs was abolished, anyone wishing to become a teacher could simply apply to the Bureauto sit a simple written test. Between 1898 and 1939, , half of the 19,136 girls who had attended normal schools operated by religious orders received a diploma, while some 80,000 of the 106,216 persons who sat the Bureau des examinateurs, obtained teaching certificates (HAMEL, 1995, p. 71). Other than those women who were members of religious orders, teaching was a temporary job for single women. Attrition rates for new teachers were very high as the conditions of living and teaching were hard, the salaries were low, and the majority of teachers taught in isolated one-room schools. Once a woman married, she was frequently forced to leave the profession. 
Compared to the Catholic teacher education sector, classes at the Protestant normal schools were co-educational. Further, unlike their Catholic counterparts, women had access to higher education through McGill University and thus were eligible to teach in secondary schools. Drummond (1990, p. 63) has argued:

\begin{abstract}
The establishment of the Québec Protestant secondary school system took place in the same decade - the $1880 \mathrm{~s}$ - in which women were admitted to the arts faculty of McGill University. This conjuncture of events produced a temporary discrepancy between the formal education of Montréal women and the teaching opportunities for women in Québec Protestant schools. In 1878, a handful of women graduated from the McGill Normal School with the Academy Diploma. Since the requirements for this Diploma included an introduction to the classics (a course of study not available to women anywhere else in Montréal) these women were qualified for entrance to the Bachelor of Arts program when McGill opened its doors to women in 1884. They received their degrees in 1888 and from that moment were among the best-qualified candidates for teaching in the Protestant public schools.
\end{abstract}

Yet Drummond (1990) further observes that, as late as the 1890 s, only $25 \%$ of protestant elementary teachers had received any type of formal teacher education. It should also be noted that the Protestant secondary education sector was more developed than the Catholic sector, where the college classiques were the only option available to enter in the university, and one reserved for the well-to-do.

The McGill Normal School was distinct from the other educational institutions in English Protestant Québec in three respects. From its founding until 1875, it was the only school with an established course of study - one which progressed from the elementary to the model school, to the academy diploma. It was also the only one to offer a course in the "Art of Teaching" as well as codes of behaviour for female and male English-speaking public school teachers; and, in proportion to the English Protestant population of Québec, its annual grant exceeded that of any English Protestant school including McGill College.

Normal schools in Québec evolved in the course of the twentieth century. As noted earlier, in Québec, with the exception of the first three normal schools founded by the state in 1857 , normal schools were administered and staffed by religious orders, some of whom received their own professional education within scolasticats-écoles normales and later within their own normal schools, open to lay pupils. From the beginning of the twentieth century onward, more 
and more religious were acquiring university degrees, at the bachelors, masters, and doctorate levels.

In an attempt to raise the standard of education delivered in the province, by midtwentieth century, an $11^{\text {th }}$ grade education was required for admission. This is an important development in the strengthening of teacher education. Teacher candidates seeking the highest level of certification enrolled in a 4-year program of study, the Brevet A. In 1957, those individuals possessing a Brevet $A$ were eligible to receive a Baccalauré at en pédagogie, to be awarded by new institutions, thus elevating teacher education credentials closer to a university level. This was a significant development because, unlike the anglophone sector that had offered teacher education at McGill University since 1907, on the Catholic francophone side, normal schools were the standard.

In the early twentieth century, some quasi-university-level teacher education programs began. In 1926 l'Institut Pédagogique de la Congrégation de Notre-Dame was established and 3years later, in 1929, I'Institut pédagogique St-Georgeswas founded by the Frères des écoles chrétiennes and was affiliated with the University of Montréal (HAMEL, 1995). Other institutions soon grew, based on a model inspired in part onthe French normal schools. In 1921 L'École normale supérieure de l'Université Lavalwas founded. In 1942 the University of Montréal established l'École normale secondaire. The year after, in 1943, l'École de Pédagogie et d'Orientation de l'Université Lavalopened its door. Finally, in 1960, l'École normale supérieure de I'Université Laval reorganized itself and the École normale supérieure de l'Université de Montréal was founded (HAMEL, 1991). The aim of all these institutions was to raise the level of preparation for different kinds of teachers, including developing teachers for normal schools and for secondary education, while leaving the preparation of elementary teachers to the religious normal schools. Because of their movement towards a university level, they were called École universitaires de pédagogie (HAMEL, 1991). During the same period, in the middle of the 1950s, the Québec sector expanded, with an increase in enrolment at the existing state normal schools of Jacques-Cartier and Laval, and with the creation of several new state normal schools situated in Chicoutimi, Trois-Rivières, Rimouski, Hull, and Rouyn-Noranda (HAMEL, 1991). Those simultaneous movements show a tendency to elevate the level of teacher training and, in certain institutions, to give it a university varnish. In the case of the École de Pédagogie et d'Orientation 
de l'Université Laval, the institution already began to develop a research agenda, supported by research grants. In the mid-1960s, three faculties of education were founded at Laval University, the University of Montréal, and the University of Sherbrooke. Even as normal schools were raising the level of teacher education, Québec society was on the eve of a tremendous transformation in all aspects of social and economic life.

A fundamental shift in Québec teacher education resulted from the recommendations of the Commission royale d'enquête sur l'enseignement dans la province de Québec (1963). The Rapport Parent was highly critical of the teacher education delivered in the normal schools. In 1962-63, there were 13,000 students educated in 106 normal schools: 11 state normal schools, 70 girls' normal schools, and 25 scolasticats écoles normales (HAMEL, 1991, p. 33). The Rapport Parent recommended that both elementary and secondary teacher education be delivered in the universities. The criticisms of the normal schools were severe, with the female normal schools singled out for the harshest assessments. They were described as offering a level of teacher preparation that was minimal; they were criticized as being too geographically isolated, too numerous serving too few students, and singularly lacking in innovation, as they were too much under the control of the Comité Catholique which approved all programs, textbooks, and examinations (HAMEL, 1991, p. 44).

The Écoles universitaires de pédagogies were also criticized by the Rapport Parent as being too isolated from the field and too autonomous from the Ministry of Education. Even the recently established faculties of education in Québec, Montréal, and Sherbrooke were assessed as not sufficiently research-oriented and not sufficiently grounded in "les sciences de l'éducation". In 1969 the government of Québec decided to transfer teacher education to the universities, and in 1974 the last cohort of normal school students finished their course. In order to be able to accomplish the new mission devolved to universities, the network of the Université du Québec was created in 1968, with satellite campuses in regional centres throughout the province. Interestingly, the state normal schools created in the mid-1950s served as a base for the new constituantes of the university du Québec: for example, in Chicoutimi, Trois-Rivières, Rimouski, Abitibi-Témiscamingue, and Hull. In Montréal, they were integrated with several other institutions to form the Université du Québec à Montréal (UQAM). Finally, the Écoles universitaires de pédagogie and the École de Pédagogie et d'orientation were more fully 
integrated into universities. The Rapport Parent also recommended that applicants to teacher education programs have a minimum of 13 years of schooling before beginning a university degree of 3years. Following that, the university-based teacher education program should include a specialized program with more practice teaching. Finally, the report concluded that teacher education should be informed by research - a primary reason to deliver teacher education inside a university setting.

Reaction to the proposed recommendations was swift and fierce. The prospect of the abolition of the normal schools led their staffs to create the Fédération des écoles normales (FEN) in order to defend normal schools - a movement which illustrates a little known element of the Quiet Revolution. Created to defend, and in a certain sense protect, the normal schools, this federation found itself at the intersection of several movements that were competing for control over teacher education: lay and religious; state and church; autonomous normal schools and universities (HAMEL, 1993). Further, the movement itself was divided. One part agreed that there should be a rationalization of services that would result in the closure of some normal schools. This group proposed to the Commission Parent that several institutions should be clustered and transformed into the centre de formation des maîtres. In fact they agreed with the elimination of both the small girls' normal schools and the scholasticats-écoles normales. Not only did they propose these changes, but they began to organize a consortium wherein several institutions pooled their resources and their students in a survival strategy to enhance the level of instruction. Another group within FEN proposed a different solution than that suggested by Rapport Parent. This group wanted teacher education to be at university level but located outside of the existing universities, arguing, "L'université comme telle, si elle peut fournir l'enseignement, n'a pas prouvé qu'elle réussit a suivre ses élèves, à leur procurer des contacts humains avec les professeurs, à les guider et à les équilibrer. Dans le grand tout il deviennent des numéros" (HAMEL, 1991, p. 78).

For FEN, it was imperative that the pedagogical education be delivered by normal schools teachers.

In spite of opposition, the integration of teacher education into the universities was mandated. Across every region of Québec, many of the smaller normal schools decided on their own to close their doors. Others decided to remain open and to fight for survival. Schools such as 
those located in Pont-rouge and St-Damien refused to abolish the Brevet B certificate program (even though it was considered too low by the reformers who wished to abolish it), arguing that their presence was necessary in their region. Others, such as the École normale Notre-Dame de Foy in Cap Rouge or the Institut pédagogique de Montréal, attempted to obtain under Article 58 of the Université du Québec Act, the status of Superior Normal School or Institute. The latter was attempting to refuse to integrate into the Universite de Montréal, arguing that its expertise in teacher education for preschool and elementary school entitled it to a privileged position. Many of the state normal schools created in the 1950s wanted to participate in the reform, and they cooperated to found the university centers (later the constituents of the Universite de Québec in the regions). Other institutions such as the École normale Laval and the École normale Mérici, both located in Québec city, reorganized themselves into coeducational institutions comprised of both lay and religious students in order to offer a more specialized program and to enrol sufficient high quality students. One short-lived experiment that stands as a testament to exploring alternative means of delivering teacher education was the creation of a campus in Cap Rouge, on the outskirt of Québec. Established by several religious orders, it offered teacher education outside the university. Even before the implementation of the findings of the Rapport Parent was mandated, universities began to organize faculties of education, sometimes using as a base the École de type universitaire such as the École normale supérieure and École normale secondaire in Montréal and later l'Institut pédagogique St- Georges.

Oral history interviews on the closure of the normal schools reveal much about this complex period in Québec educational history (HAMEL, 1991). Reflecting on the reform of the normal schools elicited many different reactions from former masters. Some realized that the Rapport Parent was suggesting the worst: the complete elimination of the normal schools. Others recalled that the Rapport Parent failed to take into account the reforms that normal schools themselves were undertaking in order to raise the level of teacher education. Some agreed that normal schools should be closed, while others wanted to protect some of them, especially those in the most remote areas of the province, in order to both recruit and retain good potential teachers. Some normal school masters viewed this reform as the ultimate struggle between the church and the laity for control over Québec education, and viewed the elimination of the normal schools as an important step in the separation of state and church. 
The university perspective provides another interesting view on the impact of the reform of teacher education. Some professors in the faculty of education feared the impact of the invasion of the normal school spirit inside the academy. Even the authors of the Rapport Parent warned of the danger of placing teacher education within the university, as they viewed the university as a dangerous place, given its tendency to either overly theorize pedagogical practice or to ignore it. Further, locating teacher education within the university threatened the prominence of teacher education: Would its students, faculty, and programs be lost within a large institution? What would happen to the career paths of the normal school masters during the reform? Many normal school masters from religious orders did not integrate within the university. Some ceased working as the small normal schools closed. Others sought employment in private institutions, in secondary schools or, as of the late 1960s, in the Cégep system (Collège d'enseignement général et professionnel). Others retired or sought alternative employment in other enterprises of their orders, as they assessed a university career as too onerous. Masters teaching in the Écoles normales d'états fared better, as their unions negotiated terms favourable to their future employment, including opportunities for further study to gain additional credentials or employment within the public service. The transfer of teacher education into the university completely changed the credentials needed to become a teacher educator. Previously, experience as a teacher was a prime criterion; now higher degrees were essential. Some former normal school masters, in spite of their overseas studies, never did acquire a masters or a doctorate. Further, former normal school masters did not rise in university administrative ranks. As well, promotion was challenging, as the university norms for research did not privilege field engagement and publishing norms devalued activities such as textbook writing.

In the middle of the 1990s, Québec instituted significant reforms in teacher education with the dual goals of becoming more selective with respect to applicants and responding to demographic shifts. The program of study was lengthened from 3 to 4 years, with an increased emphasis on the practicum experience - sometimes at the expense of formal instruction in pedagogy and curriculum. As a result of these reforms, some universities built strong bonds with the schools associated with the practicum, thus enabling teacher candidates to become more engaged with the realities of schooling. 


\section{TEACHER EDUCATION IN ONTARIO: FROM APPRENTICESHIPS TO NORMAL SCHOOLS}

As was the case in Québec, prior to the mid-nineteenth century, providing education to children scattered throughout an expansive geographic area characterized by a sparse and farflung population was a challenge. Teaching was unregulated and the domain of entrepreneurs whose personal and professional characteristics were as diverse as the students they gathered around them. E. Jane Errington (1995) demonstrates through an analysis of colonial newspapers the extent to which women entrepreneurs established private schools as economic ventures to provide basic education and to carve out employment for themselves. These schools were unregulated and staffed primarily by women who relied on their own educational experience for the knowledge and skills to equip them to teach children. Community-based, apprenticeship oriented models of preparing individuals to teach existed well after the establishment of institutions specifically dedicated to teacher preparation (GIDNEY; MILLAR, 2012).

Once a state-regulated public education system was established, a state-regulated institution for the instruction of teachers began. In Ontario (Upper Canada), the first teacher education institution, the Toronto Normal School, opened in November 1847. The origins and significance of the name "Normal" appeared annually in the teachers' colleges calendars: "The word Normal signifies according to the rule or principle and is employed to express the systematic teaching of the rudiments of learning [...]. A Normal School [...] is a school in which the principles and practices of teaching according to the rule are taught and exemplified" (ONTARIO DEPARTMENT OF EDUCATION, 1968, p. 9).

Unlike their British counterparts, Canadian normal schools were coeducational, designed for day (not residential) pupils, and, outside of Québec, were not denominationally affiliated. As was the case elsewhere across Canada, the state regulated normal schools adapted to local conditions with admission, length of program, and engagement with students in a practicum setting, whose length varied over time. In Ontario, until the early twentieth century, when it was terminated, some teachers who may have achieved junior matriculation (Grade 10) would have begun their preparation in model schools and served as untrained apprentices to teachers who were frequently not much older than themselves. They may have followed up that initial preparation through attendance at a normal school program. By 1950, for those who completed 
4 or 5 years of high school, the program length at the seven normal schools varied from 1 (including summer studies) to 2 calendar years, depending on the credentials presented by the candidate.

By mid-twentieth century, normal schools were renamed teachers' colleges. Regardless of the name, these institutions were characterized by a division of labour based on gender: a predominantly male staff teaching a student body that was overwhelmingly female. The teaching staff, significantly called masters, were principals who had previously served as classroom teachers. By joining the teachers colleges, they became civil servants. The few women who held positions were those in female-dominated subjects such as domestic science, women's physical education, and primary learning. While the majority of masters had acquired an initial postsecondary degree, some had master's degrees, and a few had doctorates. In addition to teaching the student teachers, the teaching masters worked through the summer delivering professional development courses to practicing teachers. They frequently relocated during the summer months to deliver courses at other colleges throughout the province. Some masters engaged in textbook writing and research in the areas of child development, although scholarship as defined by research and publication was not a part of their job description.

The history of preparing students to teach in secondary or high schools brings into focus the question of the relationship between academic preparation and pedagogical practice. Looking at the case of Ontario, two of the nineteenth-century experiments - one in Hamilton and the other in Toronto - failed because of a lack of support from the academy and the field. The Toronto School of Pedagogy, established by the Department of Education in 1890, failed because of lack of support from both the university and the field. The University of Toronto faculty assessed the school as both unnecessary and redundant, as the university asserted that students received adequate preparation within their discipline-based study. In the field, the Toronto Board of Education did not support the use of its secondary school teachers and their classrooms as hosts for the student teachers.

Hamilton was the location of the short-lived Ontario Normal School, which attempted to address the latter problem. The normal school was a partnership between the Board of Education and the Department of Education. Located within a building that also housed the 
Hamilton Collegiate, the Hamilton Spectator $(1895$, p. 3) celebrated its creation in an article entitled "A Good Thing for Hamilton":

\begin{abstract}
The presence in the city of say 100 intelligent and highly educated teachers in training, many of whom will be university graduates from all over the province for nearly the whole year [term is 1 October-31 May] cannot fail to leave its impression on the whole city. The students of the Collegiate will strive to reach the same height of learning as those teachers in training with whom they come daily into contact. The teachers of the collegiate will have to be more watchful as they will be constantly observed by those sent here to be trained. When a teacher is wanted on the staff of the city schools the board will have the pick of the best of the teachers in training.
\end{abstract}

Students would work with a "critic teacher," an experienced classroom teacher whom the students would observe and from whom they would learn classroom management and curriculum.

The Ontario Normal School experiment was terminated in 1907 when the Royal Commission on the University of Toronto recommended that two faculties of education be established to educate teachers for secondary schools: one at Queen's University, Kingston, and one at the University of Toronto. Yet these experiments were also short lived. By the 1920s, the faculty of education at Queen's was closed and the faculty of education at the University of Toronto became the Ontario College of Education, an institution for educating secondary school teachers, co-managed by the university and the Department of Education (SMYTH, 2003). It was not until the mid-twentieth century that widespread changes in teacher education occurred and Ontario adopted the model of university-based teacher education for all its teacher candidates, a model that had existed in Alberta since the 1940s.

As Gidney (1999) has meticulously analyzed, the 1960s saw calls for reform in education in general and teacher education specifically. Two ministerial committees were launched. One was the 1961 Committee on the Training of Secondary School Teachers, which was mandated to explore the complex academic and non-academic relationships among the provincial teachers colleges, the provincial universities, and the Department of Education. The second explored elementary teacher education through a committee chaired by C.R. MacLeod, Superintendent of Public Schools and Assistant Director of Education of the city of Windsor. The Report of the McLeod Commission (1966, p. 11) found: 
Ontario has so far continued to prepare its teachers in a one-year program following secondary school graduation. It is not surprising, therefore, that elementary teachers in Ontario have not won the professional status achieved by teachers in some other jurisdictions [...]. There appears a growing conviction among thoughtful parents and the public at large that most graduates from our Teachers' Colleges are too young, too immature and less well prepared academically than they should.

In order to produce "a scholar and an educated person" the McLeod Report (1966, p. 56) recommended that all teacher education programs be delivered within a university setting, offering students two options: concurrent (education subjects taken alongside of a degree in another academic discipline) or consecutive (an education program taken at the completion of a degree). At the heart of both options was an internship. Finally, the McLeod commission recommended an end to segregation of preparation based on the level of pupils to be taught. They concluded that elementary and secondary teacher candidates should be educated together in a program that resulted in a university degree and professional certification. Premier William Davis, who also held the office of Minister of Education, announced on March 29, 1966, his "agreement with the program suggested and it will be the policy of my department to implement the plans to this end as quickly as possible" (ONTARIO LEGISLATIVE ASSEMBLY, 1966). Universities formed a coalition to ensure that admission qualifications for students, program standards, faculty qualifications, and financial issues would be based on the same standards across the province. Several years of debate and struggle ensued as teachers colleges were transitioned into faculties of education. The universities were concerned about standards, maintaining their autonomy, and the academic credentials of the teachers colleges' masters. The records of debates within the Senate of Lakehead University $(1969$, p. 7) in Thunder Bay detail these challenges:

To Civil Servants who are on the staff of Lakehead Teachers' College on June 30 1969, and transfer to Lakehead University, the University may grant tenure at any time, but where the University does not wish to offer tenure to any such member of the staff transferred to Lakehead University, the University shall give such member one year's notice of intention not to grant tenure, the separation to become effective June 30, 1973, provided that where tenure has not been offered by June 30, 1973, the Department of Education and the University will offer assistance to the person concerned in obtaining other employment and where no notice of intention not to grant tenure is given to any such member within these three years next following June 30, 1969 , the University agrees to grant tenure to such member. 
In spite of such rhetoric, the majority of teachers college masters did find their ways into the universities. Yet, they found themselves working under different conditions. Lakehead University's founding Dean, Jim Angus (1970, p. 3) described their changing work life. Previously, it was:

\footnotetext{
[...] relatively peaceful and unharried [...] There has been no compulsion on Teachers' College Masters as there is on Professors in Faculties of Education in other jurisdictions to take advanced degrees, conduct research, publish, assume leadership in professional organizations, serve on academic committees, or deliver scholarly activity on which promotion, tenure, or merit increases in salary are normally based. This is not to suggest that some Teachers' College Masters have not done these things. Rather the point is being made that there has been no endemic need to do them.
}

As university professors, their jobs were to teach, do research, and engage in service, following a 12-month calendar - much different from their previous world. Their students were of a different ilk: they must meet the same admission standards as all other students. No longer was education a course for those who did not qualify for university education. Education students entered the classroom with one or two university degrees, demanding higher salaries and indeed, greater respect.

In the 40-plus years since the closure of the teachers' colleges, Ontario's university based teacher education expanded, changed, and diversified, shaped by forces both within and outside of its control (FLEMING, 1971). As a result of the implementation of the recommendations of the Royal Commission on Learning (ONTARIO MINISTRY OF EDUCATION, 1995), the course of teacher education changed once again. In 1997, the College of Teachers was created, transforming teaching into a self-regulated profession. The College of Teachers was given the power to accredit faculties of education and through its standards exert influence over many components of a teacher education program. Beginning in 2015, teacher education in Ontario is now a 2-year program, which includes extended practicums.

Thirteen Ontario universities offer concurrent or consecutive teacher education programs - on a full-time or, in one instance, a part-time basis. The programs offer a variety of options: courses offered in English or French, specialized programs for teachers of Aboriginal students, programs preparing teachers of physically and intellectually exceptional pupils, programs focusing on meeting the needs of diverse religious populations, and programs preparing teachers of technology studies (KITCHEN; PETRARCA, 2013, 2014). 


\section{THE HISTORY OF TEACHER EDUCATION ACROSS THE TWO PROVINCES - AND BEYOND}

Reviewing this history of teacher education in Québec and Ontario, one can clearly observe the tensions inherent in professional education. This is not unexpected as teacher education sits at the nexus of the profession, the external credentialing agencies, the university, the state, and the larger academic discipline of education.

In both contexts, despite differences in rhythm and types of reform, teacher education changed from an apprenticeship type to a university-based model, where multiple (and sometimes competing and contradictory) forces attempted to regulate the profession. In Ontario, universities prepare teachers within programs credentialed by the College of Teachers and regulated by the Ministry of Training, Colleges, and Universities, offering a curriculum heavily influenced by the Ministry of Education. Québec relies on the work of committees within the Ministry of Education (mainly the CAPFE - Comité d'agrément des programmes de formation à l'enseignement) and teacher union structures to regulate the profession.

Faculty in both provinces confront pressures from without and within. They must prepare well educated teachers for schools while at the same time producing research and publications that will enable them to meet the criteria for tenure and promotion. Further, in-class instruction competes with field-based practica, often with challenging results. In addition, the chronic underfunding of post-secondary education places additional pressures, as retiring faculty are frequently not replaced. These examples illustrate a dialectic of inclusion and exclusion, not to speak of delicate relations between the different faculties contributing to teacher training in the university.

Lakehead University Dean Jim Angus (1970, p. 3) described teacher education in Ontario as:

[...] a foster child in the Ontario educational family. It came late into the family - after the institution of the public school system, after the creation of the Department of Education, after the provision for inspectoral and supervisory services [...] [a] foster child [who by the mid-twentieth century] had become a pretty ragged Cinderella. A Prince Charming was needed to rescue it from the ashes of public neglect and intrinsic apathy. The question was where to find one. 
This description can also be applied to Québec - and indeed, to teacher education across

Canada. For well over a century, university-based teacher education was seen as the solution for all of teacher education's problems. For, as future rector of Queen's University, Kingston, S. W. Dyde (1904-1905, p. 177) observed:

\begin{abstract}
Wherever a profession is thoroughly organized, the professional training is carried on side by side with the liberal training of "Arts." Teachers are the only exception [...]. Only those who look forward to positions in high schools are found in college. The others never spend an hour within the walls of a university. It is obviously not possible yet to demand an Arts degree of all teachers in the province and yet that is an ideal towards which we should move [...]. At last teaching may become a real profession, the aloofness of the university may disappear, something approaching to educational solidarity and brotherhood be established and every schoolhouse even in the remotest settlement reap the advantage.
\end{abstract}

Yet, as even Ontario ventured into the domain of university-based teacher education, the architect of this initiative, Deputy Minister of Education J. R. McCarthy (1970, p. 7), warned:

\begin{abstract}
It will be the task of the faculty of education to justify its position in the total university context [...]. They will attempt to win academic respectability with the university by attempting to meet the criteria of academicians who know little or nothing about professional education. If they succumb to such blandishments, they will eventually lose their reason for being; first because they will be a poor shadow of arts or science faculties; and second because they will be useless in terms of the school system.
\end{abstract}

As teacher education in Canada enters into its fourth century, the warnings issued by McCarthy still ring true, along with a growing laundry list of challenges as teacher education attempts to serve its multiple masters. This chapter began with a reference to educating First Nations pupils. This is perhaps one of the most pressing challenges that Canada as a nation faces. As Battiste (2002, p. 25) asserted, "All teachers have been educated in Eurocentric systems that have dismissed Indigenous knowledge and pedagogy". While universities across the country have attempted to use a number of models to address this issue, success is, at best, mixed (BARMAN, HEBERT; MCCASKILL, 1987; ARCHIBALD, 2008; BELL, 2004),

Teacher education has been caught within the pulls of supply and demand. While ministries of education imposed caps on enrolment, individuals seeking to gain teacher education have sought venues outside the publicly funded education system to do so. In some provinces, ministries of education have approved - but not funded - teacher education programs at denominational universities, such as Ontario's Redeemer University and Tyndale University. In 
more recent years, as globalization influenced higher education, international universities have colonized Canada, with schools such as Australia's Charles Stuart University, which until 2015 offered teacher education programs at satellite Canadian campuses. The other side of this coin is the treatment of foreign trained teachers who seek recognition of their credentials. While it is the regulatory agencies (such as the Ontario College of Teachers) that approve credentials, faculties of education have partnered with these agencies to offer transitional programs to enable credentials to be recognized.

Among the contemporary challenges facing faculties of education that have historical roots, one of the most persistent is the lack of diversity within the ranks. The gender gap among pupils persists. University-based teacher education was seen as a means to attract male students. Almost a century after some form of university-based teacher education was initiated (and, indeed, half century after it was mandated in most provinces), teaching remains a highly feminized profession. Further, most provinces have attempted to diversify the application pool and have encouraged applicants to self-identify as members of underrepresented populations, but with little success. As well, retention of new teachers beyond the first 5years is a problem that still persists. New teachers still experience isolation, lack of support, difficulties in classroom management, and challenges in negotiating the politics that lie at the intersection of the classroom and the community. Experiments have been undertaken by faculties of education across the country to employ strategies to mentor their graduates during the initial phase of their careers.

In the absence of a federal agency and a national policy regulating teacher education, the informal Association of Canadian Deans of Education serves as a professional organization within the Canadian Society for the Study of Education. While it does not have the power of the American National Council for Accreditation of Teacher Education to set professional standards for program accreditation, since 2005, it has developed a number of accords on such topics as Initial Teacher Education, Indigenous Education, Educational Research, Early Learning and Early Childhood Education, and the Internationalization of Education (ACDE, 2014). This group does have the potential to influence the history of teacher education as it enters into its fourth century. 


\section{REFERENCES}

A GOOD thing for the Hamilton. The Hamilton Spectator, 14 August 1985. n.p.

ANGUS, J. T. A new direction in teacher education in Ontario. Address, Teacher Education section of the Ontario Education Association, 1970.

ARCHIBALD, J. Indigenous storywork: educating the heart, mind, body and spirit. Vancouver, BC: UBC, 2008.

ASSOCIATION OF CANADIAN DEANS OF EDUCATION (ACDE). Accords. Retrieved from: <http://www.csse-scee.ca/acde/accords>. 2014.

AUBIN, P. (Ed.). 300 ans de manuels scolaires au Québec. Montréal, QC: Bibliotheque et Archives nationales du Québec; Québec, QC: Université Laval, 2006.

BARMAN, J. H.; MCCASKILL, D. Indian education in Canada: volume 2: The challenges. Vancouver, BC: UBC, 1987.

BATTISTE, M. Indigenous knowledge and pedagogy in First Nations education: A literature review with recommendations. Paper prepared for the National Working Group on Education Available and the Minister of Indian and Northern Affairs. Retrieved from: <http://www.afn.ca/ uploads/files/education/24._2002_oct_marie_battiste_indigenousknowledgeandpedagogy_lit_re view_for_min_working_group.pdf>. 2002.

BELL, D. Sharing our success: ten case studies in Aboriginal schooling. Kelowna, BC: Society for the Advancement of Excellence in Education (SAFE), 2004.

COMMISSION royale d'enquête sur l'enseignement dans la province de Québec. Rapport de la Commission royale d'enquête sur l'enseignement dans la province de Québec (Vols. 1-5). Québec, QC: du Québec, 1963.

CURTIS, B. Ruling by schooling Québec: conquest to liberal governmentality - a historical sociology. Toronto, ON: University of Toronto, 2012.

DRUMMOND, A. Gender, profession, and principals: The teachers of Québec Protestant academies, 1875-1900. Revue d'histoire de l'éducation/Historical Studies in Education, v. 2, n. 1, p. 59-71, 1990.

DUFOUR, A. Les maîtresses d'écoles indépendantes: Une contribution essentielle à l'éducation de la jeunesse montréalaise du premier tiers du XIX siècle. In: TARDY, E. (Ed.). Les bâtisseuses de la cité: actes du colloque les bâtisseuses de la cité dans le cadre de la section d'études féministes du congress de l'ACFAS 1992. Montréal, QC: Université de Montréal, 1993. p. 124-139.

DUFOUR, A. Les institutrices du Bas-Canada: incompetentes et inexperimentées? Revue d'histoire de l'Amérique française, v. 51, n. 4, p. 521-548, 1998. 
DUFOUR, A. Les premières enseignantes laïques de Québec: le cas de Montréal, 1825-35. Histoire de l'education, Paris, v. 198, p. 3-32, 2006.

DYDE, S. W. Should there be a faculty of education in the university? Queen's Quarterly, v. 12, p. 177, 1904.

ERRINGTON, E. J. Wives and mothers, school mistresses and scullery maids. Working women in Upper Canada, 1790-1840. Montréal, QC: McGill-Queen's, 1995.

FALKENBERG, T. (Ed.). Handbook of Canadian research in initial teacher education. Ottawa, ON: Canadian Association for Teacher Education: 2015.

FLEMING, W. G. Ontario's educative society: Supporting institutions and services. Toronto, ON: University of Toronto, 1971.

GALARNEAU, C. Les collèges classiques au Canada-francais (1620-1970). Montréal, QC: Fides, 1978.

GALARNEAU, C. Les écoles privées à Québec, 1760-1859. Cahiers des dix, v. 45, p. 95-113, 1990.

GIDNEY, R. From Hope to Harris. Toronto, ON: University of Toronto, 1999.

GIDNEY, R. D.; MILLAR, W. P. J. How schools worked: Public school in English Canada, 1900-1940. Montréal, QC: McGill-Queen's University, 2012.

HAMEL, T. Le déracinement des écoles normales: le transfert de la formation des maîtres à I'université. Québec, QC: IQRC, 1991.

HAMEL, T. Les religieuses enseignantes auraient-elles fait la Révolution tranquille si on leur en avait laissé le temps? In: TARDY, E. (Ed.). Les bâtisseuses de la cité: actes du colloque les bâtisseuses de la cité dans le cadre de la section d'études féministes du congress de l'ACFAS 1992. Montréal, QC: Université de Montréal, 1993. p. 149-166.

HAMEL, T. Un siècle de formation des maîtres au Québec, 1836-1939. Montréal, QC: HMH, 1995.

KITCHEN, J.; PETRARCA, D. Teacher preparation in Ontario: A history. Teaching and Learning, v. 8, n. 1, p. 56-71, 2013.

LEBRUN, M. (Ed.). Le manuel scolaire: D'ici et d'ailleurs, d'hier à demain. Québec, QC: Université du Québec, 2007.

MACLEOD, C.R. (Chair). Report of the Minister's Committee on the Training of Elementary School Teachers. (The Mcleod Report) Toronto, ON: Ontario Department of Education, 1966. 
MCCARTHY, R. From Teachers' Colleges to Faculties of Education. In: REES, W. (Ed.). Teacher education: a search for new relationships. Toronto, ON: Ontario Institute for Studies in Education, 1970. p. 3-11.

ONTARIO DEPARTMENT OF EDUCATION. Calendar of Teachers' Colleges, 1968.

ONTARIO LEGISLATIVE ASSEMBLY. Debates and Proceedings, 200ge. 1966, March 28.

ONTARIO MINISTRY OF EDUCATION. For the love of learning: Royal Commission on Learning. Retrieved from: <https://www.edu.gov.on.ca/eng/general/abcs/rcom/full/volume3/sectionb.pdf>. 1995.

SENATE OF LAKEHEAD UNIVERSITY. Senate minutes (Meeting 3S) [Proposed agreement between the Minister of Education and Lakehead University, regarding the matter of Teacher Education]. 1969, March 22.

SMYTH, E. "It should be the centre... of professional training in education": The Faculty of Education of the University of Toronto, 1871-1996. Tidskrift, v. 3-4, p. 135-152, 2003.

SMYTH, E. Learning to teach: Ontario's elementary school teacher education 1960-1974. Education Research and Perspectives, v. 33, n. 2, p. 80-101, 2006.

SMYTH, E.; HAMEL, T. The history of initial teacher education in Canada: Québec and Ontario. FALKENBERG, T. (Ed.). Handbook of Canadian research in initial teacher education. Ottawa, ON: Canadian Association for Teacher Education: 2015. p. 115-128.

VERETTE, M. The spread of literacy. In: FLEMING, P.; GALIICHAN, G.; LAMONDE, Y. (Ed.). The history of the book in Canada: beginnings to 1840. Toronto, ON: University of Toronto, 2004. p. 167-171.

Recebido em março de 2016.

Aceito em abril de 2016. 